\title{
The Meaning of Culture Pasang Ri Kajang Communities
}

\author{
Emil Fatra ${ }^{1}$, Muh. Iqbal Sultan ${ }^{2}$, Tuti Bahfiarti ${ }^{3}$ \\ Program Studi Ilmu Komunikasi Fakultas Ilmu Sosial dan Ilmu Politik, Universitas \\ Hanasuddin, Jalan Perintis Kemerdekaan KM. 10 Makassar 90245 \\ Telepon (0411) 585024 /Fax (0411) $585024^{1,2,3}$ \\ \{emilfatra21@gmail.com¹,miqsul1012@gmail.com², tutibahfiarti@yahoo.com³
}

\begin{abstract}
The Ke-ammatoan community is closely related to the lifestyle governed by the values of Pasang Ri Kajang. In essence, this study aims to reveal the cultural meaning of Pasang Ri Kajang in the ke-ammatoan community and to find and categorize pasang Ri Kajang's meaning. This study uses a qualitative research method through a phenomenological approach by collecting data through observations, interviews, and documentation studies. The results of the study found that there are five meanings of the culture $R i$ Kajang, namely (1) love for God (PairTuriek Ar Arti), (2) To Kamase-masea principle, which means simplicity of life, (3) act decisively in any aspect, (4) Lambusu Na' Gattang which means obeying the rules in the, and (5) Deliberation (Abborong). These five things are adapted in the ke-ammatoan community's life, especially in preserving nature and the environment.
\end{abstract}

Keywords: Culture; Pasang Ri Kajang; Ammatoan Community

\section{Introduction}

The Kajang tribe or the ke-ammatoan community is a tribe (sub-ethnic) living in the interior of Makassar, South Sulawesi. They have lived and resided in Kajang District, Bulukumba Regency, about 150 kilometers from the east of Makassar City from generation to generation. The ke-ammatoan community is divided into two groups, namely the outer and inner Kajang. The outer Kajang has lived and accepted technology or modernism. Simultaneously, the inner Kajang maintains tradition and culture by having a different lifestyle in general, namely living separately and not experiencing modernism. The ke-ammatoan community is synonymous with all black clothes, from the head covering to the sarong that covers the body. They believe that no black color is better than one another. All black is the same; black to him is strength, equality. This community is led by Ammatoa (tribal head). Ammatoa is believed to be the best human being represented by God to convey the truth. Uniquely community All these Ammatoaan have confidence called Ri Kajang Posting messages (ancestors), confidence in the tides implemented and believed to be in their lives. One of their beliefs is the existence of natural wonders (macrocosm). The Pasang Ri Kajang itself was revealed to someone who was nicknamed Ammatoa (traditional leader) by God Almighty (Darmapoetra, 2014). 
The strong influence of animism and dynamism still spreading today has made the keammatoan community tend to get stereotypes from the general public. Through the understanding of the tides, they have a way of life by implementing the principle of Kamasemasea To live in simplicity (Sampean, 2017). Let us examine the concept of simplicity more deeply. The ke-ammatoan community is that life is not based and controlled by lust that blindly moves humans to become greed perpetrators. The difference in the way of life of the ke-ammatoan community was managing their natural resources to support them. They have not destroyed nature in their life so far (Rahmayani et al., 2017). The ke-ammatoan community has made nature their mother; in other words, hurting a mother is a big sin that should not be committed.

The ke-ammatoan community is substantial in preserving the traditional values that have been followed since their ancestors lived. This persistence is proven by rejecting technology from entering areas such as electricity, motorbikes, and other means of modernism. They believe that technology's influence is very bad for humans; therefore, they reject all forms of technology. The ke-ammatoan community assumed technology is considered to damage the environment and the universe and disrupt the preservation of their culture. This is following research conducted by showing that the Ammatoan community is very closed, and there are taboos (kasipalli) in their lives (Hijjang, 2014). Meanwhile, the study conducted found that the Ammatoaan people distance themselves from technology because it can damage the way of life of the ke-ammatoan community, moreover it can cause them to destroy forests and the environment (Syarif et al., 2016). The ke-ammatoan community is one of the many ethnic groups with a life pattern that is bound by traditions and commands of God. In this case, the ke-ammatoan community has relied on Turiek Ar Arakna (God) all worldly affairs without damaging the environment. This has been stated in a belief called patuntung, which provides human truth in living his life. This includes how the ke-ammatoan community protects nature and the environment by not destroying or even destroying what Turiek Arakna (God) has given in this life.

Loving nature is an identity attached to this community, so that the ke-ammatoan community makes nature an essential part of this life. They think that everything that God has created must be properly maintained and managed, especially forests and nature. The keammatoan community has formulated an understanding that nature will provide long life (Akib, 2003).

The ke-ammatoan community is known to believe in the culture, Pasang Ri Kajang firmly. Pasang Ri Kajang itself is a way of life that has been understood and interpreted for years, has become a source of life and local strengthening for the ke-ammatoan community. The implementation of local values in the customary area of Ke-Ammatoaan is a manifestation of a culture called Pasang Ri Kajang. They understand that Pasang Ri Kajang has outlined a life value second to none in this world. So in every aspect of the ke-ammatoan community's life, he departs from the Pasang Ri Kajang value. As loyal adherents, they are disciplined in carrying Pasang Ri Kajang with their consistency to create a strong community life during the modernism era.

The beauty and environmental sustainability of the ke-ammatoaan community forest are proof of the adaptation and implementation of the Pasang Ri Kajang value. Collectively, they understand the noble values contained. Therefore, it is exciting and makes researchers want to reveal the meaning of Pasang Ri Kajang in the Ammatoan Community in Bulukumba Regency.

Therefore, because we want to know Pasang Ri Kajang more deeply, the researchers have raised this research to be packaged and given the truth. The purpose of this research has 
promising implications for local cultures such as those in the Regency Ammatoan Community Bulukumba.

\section{Literature Review}

\subsection{Culture}

Culture is concerned with the way humans live. Humans learn to think, feel, believe and strive for what is appropriate according to their culture. Culture is a concept that arouses interest. Culture is formally defined as an order of knowledge, experience, beliefs, values, attitudes, meanings and is passed down from generation to generation through individual or group efforts. Culture is continuous and ubiquitous, and culture also deals with the physical form and social environment that affects our lives. Our culture inevitably affects us from the womb to death and after death. If linked in communication, these two things cannot be separated because culture not only determines who speaks who, about what, and how communication takes place, but culture also determines the person encoding the message, the meaning he has for the message, and the conditions for sending, pay attention to, and interpret messages (Sihabuddin, 2013).

\subsection{Cultural Communication}

Research on cultural communication began in the 1950s and 1960s, accompanying the wave of globalization (McLuhan, 1962) and the emergence of the post-World War II United States as a world power. Cultural communication is generally defined according to two main concepts, culture and communication. The anthropological concept of culture (culture) has been used to label culture's collective life experience in a society or nation. Over time, this domain has expanded to include communication activities involving individuals from various domestic sociological groups with various backgrounds, such as ethnicity, race, and other social categories. Cultural communication is thus broadly defined as a communication process that occurs within cultural community groups. Cultural communication is one of the many elements in this life; by him, cultural communication is still spreading and living in this life (Berger R, 2015). Cultural communication research has aimed at identifying unique communication patterns or those currently prevailing in a particular culture. Of course, this concept is by what the researchers raised regarding Pasang Ri Kajang's cultural meaning in the ke-ammatoan community in Bulukumba district.

\subsection{Phenomenology}

Phenomenological research tries to understand people's perceptions, perspectives, and understanding of a particular situation (or phenomenon). In other words, a phenomenological study tries to answer the question, "how does it feel to experience this and that?" By looking at the same situation's perspective, the researcher can make some generalizations about an experience from an insider perspective. However, phenomenology is one of the many types of research approaches used to examine human life experiences. Phenomenology researchers hope to obtain essential truths from life experiences (Sobur, 2014). 


\subsection{Symbolic Interaction Theory}

The notion of symbolic interaction is a way of thinking about the mind, self, and society that has contributed a lot to the sociocultural tradition in building communication theory. George Herbert Mead is seen as the builder of this symbolic interaction. He taught that the meaning emerged as a result of interaction between humans both verbally and non-verbally. Then, in symbolic interactionism, it is emphasized that an object can be a particular aspect of personal reality, whether it is an object, quality, event, situation, or state that has been given meaning in a specific community (Morissan, 2013).

\section{Method}

\subsection{Research Design}

The paradigm used in this study is a qualitative interpretive research method, using a phenomenological approach that aims to find meaning through direct experience. Phenomenology makes experience the primary data source in this study. Thus, in this study, the researchers used phenomenology to find the meaning of Pasang Ri Kajang by the keammatoaan community (Morissan, 2013).

\subsection{Research Object}

The object of this research is Pasang Ri Kajang which becomes sacred in the ke-ammatoan community. The interesting thing is why researchers are interested in studying the existing culture in the ke-ammatoan community because they still adhere to their ancestors' teachings even though they are in the midst of the development of modernism.

\subsection{Data Collection}

This research uses data collection techniques through observation, in-depth interviews, and documentation study. The researchers used the data collection techniques above because they were considered more capable of collecting data and making it easier for researchers to collect information related to the meaning of Pasang Ri Kajang in Bulukumba Regency (Mulyana, 2018).

\subsection{Data Analysis}

Furthermore, this study using data analysis techniques from Miles and Huberman. Namely, in this data analysis technique, there are three parts. The first is data condensation, namely selecting, focusing, and simplifying all the data findings. The second is the presentation of the data, namely categorizing, unifying, and writing down the information that has been obtained. Then the third is drawing conclusions, namely, collecting and drawing the threads and compiling the ending from the data that has been compiled (Mulyana, 2018). 


\section{Result and Discussion}

Pasang Ri Kajang, one of the many local pearls of wisdom in Indonesia. It is not just a name in the Ammatoan community but is considered a part that must be implemented in the ke-ammatoan community's life. One of its implementations is the prohibition of destroying nature, in this case, the forest inside the customary area of the ke-ammatoaan community. The values of Pasang Ri Kajang, which the Bulukumba people of South Sulawesi guard, have built and preserved cultural communities. According to Tylor, culture is the complexity of all knowledge, beliefs, arts, laws, customs, and every other ability and habit possessed by humans as members of a society (Aloliliweri, 2011).

The Meaning of Pasang Ri Kajang in the Ke-Ammatoaan Community in Bulukumba Regency

\section{a) Obedience to Turiek Arakna (God)}

The teachings or values of Pasang Ri Kajang in the Ammatoan community make this community obey God's commands. The Ammatoan Community manifests their obedience in protecting and managing the forest, as stated in the research. If Kajang people care for nature, then nature will protect them, giving them a sustainable life. (Kamaluddin \& Mustolehudin, 2020).

For the Ammatoan community, protecting nature and its contents is an order that must be done through Pasang Ri Kajang. The meaning of Pasang Ri Kajang is implemented in their lives. It is noted that there has never been a natural disaster that occurred in the customary area. There is only coolness and peace when the outside community enters the customary area of the ke-ammatoaan community (Hafid, 2013).

\section{b) The Principle of Tallasa Kamase-masea (The Principle of Simplicity)}

Every community and community group must have its own identity. Identity is needed to identify the existence and position of the community. Community identity is a symbol and a symbol that they have specific characteristics as identification. It has been formulated that Pasang Ri Kajang is historical in Kajang and has been interpreted with wisdom by all Ammatoan community members. Pasang $\mathrm{Ri}$ Kajang is interpreted by the Ammatoan community as the basis of life, namely applying the principle Tallasa Kamase-mase (simplicity of life).

One form of simplicity shown is the black dress inherent in the ke-ammatoan community group's daily lives. The ke-ammatoan community is physically characterized by wearing all black clothes and not wearing sandals. Black is considered a symbol of simplicity and a symbol of modesty. Simplicity is also illustrated through the form of the house of the keammatoaan community, in the area itself, the construction of houses is managed jointly (cooperation), and all necessities such as poles, roofs, and binders can be found in the keammatoaan forest area. Not only that, in the Customary Area, all house sizes and models are the same. Nothing is striking and different. They build houses very openly. The house is not built with high walls like modern houses in general.

They also display simplicity by not wearing sandals; they think that they cannot blend with nature by wearing sandals. They implement it in their lives, but the most exciting thing is that this simplicity gives good health results. In the Indigenous area, the disease called rheumatism 
is not found in members of the ke-ammatoan community. Simplicity is what makes the keammatoaan community synonymous with the term Tallasa Kamase-masea as recorded in the maktub, namely:

Ammentengko nu Kamase-mase, A'cci'dongko nu Kamase-mase, A'ddakako nu Kamase-mase, A'meakko nu Kamase-mase. Meaning: you stand simple, you sit simple, you walk simple, you speak simple.

Tallasa Kamase-masea in Pasang Ri Kajang is the life principle of the indigenous people. The ke-ammatoan community upholds this principle, and they do not expect more from the necessities of life. Although natural resources support them to get their grandeur, it is not a single person if greed is made a life partner. The peak of the simplicity they display is that they choose to protect nature to be conserved, not to be exploited for personal gain. They see the natural environment as an integral part of their life, and they protect the customs, the environment, and the forest as a form of deep meaning for Pasang Ri Kajang.

\section{c) To Act Decisively}

The Meaning of Pasang Ri Kajang is to act and act decisively in any case. The keammatoan community highly upholds a firm attitude in running life; this can be seen from the ke-ammatoan community's consistency in protecting nature and the environment. Furthermore, the meaning of Pasang Ri Kajang is related to the task of a person called Ammatoa (traditional head). Ammatoa's firmness in upholding the Pasang as a principle of social life, morals, and everything related to the relationship between heaven, humans, and local wisdom.

The meanings become complex with the application that is applied in depth. The fact is reflected in Ammatoa's ability to maintain order between all aspects and joints of social life. It could be seen from the personality and figure of the ke-ammatoan, who makes pair a fundamental principle of life. Pasang Ri Kajang is now the foundation of life for the keAmmatoaan community, making it thick with the meaning and values of life. Firmness always appears and is applied by society or the Ammatoan community.

The Kajang people's assertiveness that we can meet is the firmness in applying rules and sanctions in the ke-ammatoaan customary area. Those who violate the rules will be given customary sanctions. In the ke-Ammatoa area, the people or their community groups must obey the rules that have been written in the Posting. one of which is forest management, house building, deliberations, and ritual activities. All of these things are obeyed by members of the ke-ammatoaan community, if anyone violates them, they will be given customary sanctions as agreed. Their determination and assertiveness in managing and protecting nature have resulted in the coolness and beauty of nature. Visitors who enter both national and international visitors will feel natural sensations that are natural and since, without any pollution disturbance.

The Bulukumba Regency people have long known the ke-ammatoaan community to be firm in making decisions. If they have decided, they are not allowed to change it; for him, the firm meaning is like a promise that cannot be denied or abandoned. They are thick with an authoritarian personality. In another sense, they are humans who do not easily betray other humans. The implementation of the value of Pasang Ri Kajang, in conclusion, is that they distance themselves from worldly beauties. They are assertive because they understand that assertiveness will protect them from any influence in this world. In Pasang Ri Kajang, assertiveness is applied in words and implemented in our actions as humans. 


\section{d) Honest and Firm in Rules (Lambusu Na' Gattang)}

The Pasang Ri Kajang is third that the community meaning of ke-ammatoan upholds honesty and upholds the rules. In the Kajang Konjo language, it is called Tau Lambusu $\mathrm{Na}^{\prime}$ Gattang. They assume that honest and rule-abiding behavior will be brutal to find in today's era of sophisticated technology but not for the ke-ammatoan community. Honesty is the responsibility for life given by Turiek Arakna (God), which the ke-ammatoan community must guard. Researchers see that this community is alive and self-limiting, meaning that this community's lifestyle is different from society in general; they create a boundary line that cannot be interfered with by any party, even if it is the government.

Lambusu $\mathrm{Na}^{\prime}$ Gattang is an outline that must be implemented within all members of the ke-ammatoan community. Ammatoa as the presenter of the Tide has succeeded in carrying out its duties. The ke-ammatoaan community group is known to be very honest and obedient to the rules. Lambusu and Gattang's words reflect the way they protect the forest and manage nature. None of the ke-ammatoaan community dared to cut trees in the forest called the area Lalang Embayya. According to the rules that Ammatoa stated that in the Ammatoan area, there should be no technology, and none of them have electricity or lighting in Ammatoan area.

They are said to be a community that is steadfast in applying the rules because they have studied Pasang Ri Kajang as a guide for the Kajang people's lives. Even in his book, Juma Darmapoetra, the ke-ammatoaan community in the customary area will honestly and truthfully carry out their responsibilities and consistently obey the rules. They live and implement the meaning of their duties and responsibilities. They become trusted people even though they do not know the formal education system. As a community group, they firmly adhere to the guidelines that customs and beliefs must be upheld and values must be applied in everyday life.

This fact is reflected in the absence of criminals in the Ammatoaan customary area. Even no community members feel they have lost their objects and goods, let alone stolen. One proof that the ke-ammatoan community has made honesty and rules an inseparable part of their lives. Therefore, the meaning of Pasang Ri Kajang, the third pair, has become essential and has been actualized in the Ammatoan community group's life in Bulukumba Regency.

\section{e) Importance of Deliberation (Abborong)}

The value of Pasang Ri Kajang teaches about the importance of deliberation or in the language of Konjo Kajang it is called Abborong in any case such as forest management, nature, and decisions in the customary area of ke-ammatoaan. Through the Abborong Musyawarah activity, opinions and decisions will be generated and an agreement about the start of the planting season or the determination of the wedding day in the Ammatoaan custom. If there is already an agreement in Abborong activities, then the entire ke-ammatoaan community or community simultaneously follows the customary stakeholders' decisions. Violations that occur will exclude members of the community who violate it from all their main activities in the Ammatoaan area.

This explains that the activities or activities of the deliberation Abborong pair very much under the principles of values that exist in Pasang Ri Kajang. In pairs, it is believed that collectively agreed decisions would get blessings in carrying them out. Thus, Put Pasang Ri Kajang is by the ke-ammatoan community believed to be a message given from Turiek Arakna, a culture that contains both rights and orders to obey all its contents. 
Within the Ammatoan area, deliberation is an activity to convey opinions and an arena to find the best way if there are problems that cannot be resolved personally. This is interesting because the problems that exist within the customary area must be borne by all community members so that harmony, harmony can be realized and can lead to the creation of a strong sense of brotherhood. That is the meaning of Pasang Ri Kajang, of course not only being a symbol but being manifested and preserved by the ke-ammatoan community in Bulukumba Regency.

\section{Conclusion}

This research shows that the values of local wisdom in the cultural tradition of Pasang Ri Kajang in their life aspects have a neural meaning for the goodness and responsibility of life that all humans must apply in the area of the Ammatoaan custom. Based on the description above, researchers have reached the conclusion stage of the cultural meaning of Pasang Ri Kajang in the community, namely: there are five meanings or cultural values behind Pasang Ri Kajang. The first is through the Pasang Ri Kajang obeyed Turiek Arakna(God). Second, gave birth to the Tallasa Kamase-mase principle (living in simplicity). The third gives birth to assertiveness in acting. The fourth is applying the Lambusu Na' Gattang principle of honest and obedient behavior. The fifth is the existence of deliberation activities, or in the Konjo language, it is called Abborong. All of these meanings are applied and applied in the life of the ke-ammatoan community to this day.

\section{References}

[1] Akib, Y. (2003). Potret Manusia Kajang (1st ed.). Pustaka Refleksi.

[2] Aloliliweri. (2011). Komunikasi Antar Budaya (Kamdani (ed.); II). PUSTAKA BELAJAR.

[3] Berger R, C. R. E. M. D. (2015). The Hanbook Of Communication Science (III). Penerbit Nusa Media.

[4] Darmapoetra, J. (2014). Kajang Pecinta Kebersamaan dan Pelestarian Alam. ARUS TIMUR.

[5] Hafid, A. (2013). Belief System in Indigenous Community of Kajang in the Village. Patanjala, 5(1), 1-19. https://media.neliti.com/media/publications/291922-sistemkepercayaan-pada-komunitas-adat-k-ba042814.pdf

[6] Hijjang, P. (2014). Pasang dan Kepemimpinan Ammatoa: Memahami Kembali Sistem Kepemimpinan Tradisional Masyarakat Adat dalam Pengelolaan Sumberdaya Hutan di Kajang Sulawesi Selatan. Antropologi Indonesia, 29(3), 255-268. https://doi.org/10.7454/ai.v29i3.3545

[7] Kamaluddin, \& Mustolehudin. (2020). Pasang Ri Kajang: Nilai-Nilai Kearifan Lokal Dalam Pelestarian Lingkungan Hutan di Bulukumba Sulawesi Selatan. PENAMAS, 33(1), 133-152. https://doi.org/https://doi.org/10.31330/penamas.v33i1.385

[8] Morissan. (2013). Teori Komunikasi Individu Hingga Massa (4th ed.). PRAMEDIA GROUP.

[9] Mulyana, D. (2018). Metodologi Penelitian Kualitatif (9th ed.). PT. Remaja Rosdakarya.

[10] Rahmayani, E., Nadjib, M., \& Kahar. (2017). Pola Perilaku Komunikasi Masyarakat Di 
Kawasan Adat Ammatoa Kajang. Jurnal Komunikasi Kareba, 6(2), 361. https://doi.org/10.31947/kjik.v6i2.5339

[11] Sampean, S. (2017). Survival Etnik: Kuasa Kosmologi Dan Posisi Etnik Kajang Ammatoa Dalam Pembangunan. Journal of Islamic World and Politics, 1(1). https://doi.org/10.18196/jiwp.1108

[12] Sihabuddin, A. (2013). Komunikasi Antarbudaya (II). PT. Bumi Aksara.

[13] Sobur, A. (2014). Filsafat Komunikasi (II). PT. Remaja Rosdakarya.

[14] Syarif, E., Fatchan, A., Sumarmi, ., \& Astina, K. (2016). Tradition of "Pasang RiKajang" in the Forests Managing in System Mores of "Ammatoa" at District Bulukumba South Sulawesi, Indonesia. Mediterranean Journal of Social Sciences, 7(6), 325-332. https://doi.org/10.5901/mjss.2016.v7n6p325 